\title{
Inhibitory effect of $N$-ethyl-3-amino-5-oxo-4-phenyl-2,5-dihydro- $1 H$-pyrazole-1-carbothioamide on Haemophilus spp. planktonic or biofilm-forming cells
}

\author{
Urszula Kosikowska • Anna Malm • \\ Monika Pitucha · Barbara Rajtar · \\ Malgorzata Polz-Dacewicz
}

Received: 29 January 2013/Accepted: 8 August 2013/Published online: 23 August 2013

(C) The Author(s) 2013. This article is published with open access at Springerlink.com

\begin{abstract}
During this study, we have investigated in vitro activity of $N$-substituted-3-amino-5-oxo-4-phenyl-2,5dihydro-1H-pyrazole-1-carbothioamide derivatives with $N$ ethyl, $N$-(4-metoxyphenyl) and $N$-cyclohexyl substituents against Gram-negative Haemophilus influenzae and H.parainfluenzae bacteria. A spectrophotometric assay was used in order to determine the bacterial growth and biofilm formation using a microtiter plate to estimate minimal inhibitory concentration (MIC) and minimal biofilm inhibitory concentration (MBIC). Among the tested $N$-substituted pyrazole derivatives, only $\mathrm{N}$-ethyl-3-amino-5-oxo-4-phenyl-2,5-dihydro- $1 H$-pyrazole-1-carbothioamide showed a significant in vitro activity against both planktonic cells of H. parainfluenzae $\left(\mathrm{MIC}=0.49-31.25 \mu \mathrm{g} \mathrm{ml}^{-1}\right.$ ) and H. influenzae (MIC $=0.24-31.25 \mu \mathrm{g} \mathrm{ml}^{-1}$ ) as well as biofilmforming cells of $H$. parainfluenzae (MBIC $=0.24-31.25$ $\mu \mathrm{g} \mathrm{ml}^{-1}$ ) and $H$. influenzae (MBIC $=0.49$ to $\geq 31.25$ $\mu \mathrm{g} \mathrm{ml}^{-1}$ ). The pyrazole compound exerted higher inhibitory effect both on the growth of planktonic cells and biofilm formation by penicillinase-positive and penicillinase-negative isolates of $H$. parainfluenzae than the activity of commonly used antibiotics such as ampicillin. No cytotoxicity of the tested compound in vitro at concentrations used was
\end{abstract}

U. Kosikowska $(\bowtie) \cdot$ A. Malm

Department of Pharmaceutical Microbiology, Medical University of Lublin, Chodzki Str. 1, 20-093 Lublin, Poland

e-mail: u.kosikowska@umlub.pl

\section{Pitucha}

Department of Organic Chemistry, Medical University, Chodzki Str. 4a, 20-093 Lublin, Poland

B. Rajtar · M. Polz-Dacewicz

Department of Virology, Medical University, Chodzki Str. 1, 20-093 Lublin, Poland found. The tested pyrazole $N$-ethyl derivative could be considered as a compound for the design of agents active against both pathogenic $H$. influenzae and opportunistic $H$. parainfluenzae, showing also anti-biofilm activity. This appears important because biofilms are determinants of bacterial persistence in long-term and recurrent infections recalcitrant to standard therapy.

Keywords Haemophilus spp. · Pyrazole derivatives · Antibacterial activity · Anti-biofilm activity · Cytotoxicity

\section{Introduction}

Biofilms are sessile aggregates of bacterial cells that are created on either biotic surfaces (e.g., human tissues) or abiotic surfaces (e.g., biomaterials, catheters) and act like a single living organism that can exhibit differences in the expression of surface molecules, antimicrobial resistance, virulence factors, and pathogenicity (Costerton et al., 1999, 2003; Burmølle et al., 2010; Hall-Stoodley et al., 2012; Bjarnsholt, 2013). In medicine, biofilms have been widely associated with several chronic and recurrent diseases, chronic wound infections, and foreign body infections associated with implantable medical devices and indwelling catheters, antibiotic-resistant and nearly impossible or difficult to eradicate without aggressive and long-term interventional strategies infections (Donlan, 2001; Steward and Costeron, 2001; Gilbert et al., 2002; Stoodley et al., 2004; Lasa et al., 2005; Sanclement et al., 2005; Macfarlane and Dillon, 2007; Vlastarakos et al., 2007; Macedo and Abraham, 2009; Wolcott and Ehrlich, 2008; Coenye and Nelis, 2010; Drago et al., 2012; Bjarnsholt, 2013).

Haemophilus spp. rods, generally known as Gram-negative microbiota of the upper respiratory tract, are able to 
live as planktonic cells or colonize natural and artificial surfaces as biofilm-forming cells (Hill et al., 2000; Chin et al., 2005; Musk and Hergenrother, 2006; Galli et al., 2007; Kilian, 2007; Moxon et al., 2008; Kosikowska and Malm, 2009; Murphy et al., 2007; Drago et al., 2012; Ünal et al., 2012). Both pathogenic Haemophilus influenzae and opportunistic $H$. parainfluenzae can cause acute, chronic, invasive or non-invasive infections. These microorganisms may form a biofilm which is a virulence determinant which contributes to recurrent or chronic infections. $H$. influenzae is the most pathogenic bacteria colonizing the mucous membranes of the respiratory tract of young children or sporadically elderly people. $H$. influenzae, mainly serotype b (Hib), is frequently associated with different diseases, e.g., otitis media, chronic bronchitis, and pneumonia (Agrawal and Murphy, 2011). Other illnesses caused by this species include osteomyelitis, arthritis, sepsis, phlegmon cellulitis, or abscesses. Non-typeable $H$. influenzae (NTHi) is one of the main causes of airway infection in chronic obstructive pulmonary disease, of recurrent otitis media in infants and children, sinusitis in children and adults, pneumonia in adults, lower respiratory tract infection in adults, and recurrent respiratory tract infections in patients with chronic bronchitis (Murphy, 2003; Erwin and Smith, 2007).

Haemophilus parainfluenzae is an opportunistic pathogen, which may cause several endogenous diseases occasionally and under predisposing conditions (e.g., chronic diseases or immune disorders) such as respiratory tract infections, endocarditis, biliary tract infection, septic arthritis, thoracic empyema, meningitis, secondary bacteremia, urethritis, and hepatic abscesses (Chow et al., 1974; Cooney et al., 1981; Warman et al.; 1981; Raoult et al., 1987; Darras-Joly et al., 1997; Das et al., 1997; Bottone and Zhang,1995; Pillai et al., 2000; Frankard et al., 2004; Cardines et al., 2009).

Nitrogen heterocycles, including pyrazoles, are important group of natural or synthetic derivatives with a broad spectrum of biological and pharmaceutical activities, e.g., antibacterial, antifungal, antiviral, anti-inflammatory, antipyretic, anticancer, and anticonvulsant (Comber et al., 1991; Mahajan et al., 1991; Chauhan et al., 1993; Sugiura et al. 1977; Bekhit and Abdel-Aziem, 2004; Gökhan-Kelekçi et al., 2007; Lin et al., 2007; Kumar et al., 2012). Much attention has been paid to pyrazole derivatives due to their wide range of antibacterial activities as potential and selective inhibitors against DNA gyrase capable of causing bacterial cells' death (Reece and Maxwell, 1991; Maxwell, 1997; Tanitame et al., 2004; Liu et al., 2008; Shiroya et al., 2011). $N$-ethyl-3-amino-5-oxo-4phenyl-2,5-dihydro- $1 H$-pyrazole-1-carbothioamide, synthesized according to Pitucha et al. (2010) appears to be a promising precursor of agents with good activity mainly against Gram-positive bacteria - both pathogenic, including Staphylococcus aureus (MIC $=7.81-62.5 \mu \mathrm{g} \mathrm{ml}^{-1}$ ) as well as opportunistic, e.g., S. epidermidis, Bacillus spp. or Micrococcus luteus with $\mathrm{MIC}=3.91-31.25 \mu \mathrm{g} \mathrm{ml}^{-1}$ (Pitucha et al., 2010). The inhibitory effect against Gram-negative bacteria-belonging to Enterobacteriaceae family (Escherichia coli, Klebsiella pneumoniae, and Proteus mirabilis) or nonfermentative rods (Pseudomonas aeruginosa) was weaker $\left(\mathrm{MIC}=250-1,000 \mu \mathrm{g} \mathrm{ml}^{-1}\right.$ ). In this paper, we have investigated in vitro activity of pyrazole derivatives, among which $\mathrm{N}$-ethyl-3-amino-5-oxo-4-phenyl-2,5-dihydro- $1 \mathrm{H}$ pyrazole-1-carbothioamide showed highest activity against planktonic and biofilm-forming cells of $H$. influenzae and $H$. parainfluenzae.

\section{Results and discussion}

According to our preliminary results, $N$-(4-metoxyphenyl)3-amino-5-oxo-4-phenyl-2,5-dihydro- $1 \mathrm{H}$-pyrazole-1-carbothioamide compound had very low inhibitory effect on the growth of planktonic cells of the reference strains of Haemophilus spp. (MIC $=500-1,000 \mu \mathrm{g} \mathrm{ml}^{-1}$ ), similar to $N$-cyclohexyl-3-amino-5-oxo-4-phenyl-2,5-dihydro- $1 H$ pyrazole-1-carbothioamide which inhibited the growth of these bacteria with somewhat lower $\mathrm{MIC}=125-500$ $\mu \mathrm{g} \mathrm{ml}^{-1}$. Among the tested pyrazole derivatives, $N$-ethyl3-amino-5-oxo-4-phenyl-2,5-dihydro-1H-pyrazole-1-carbothioamide derivative showed a significant in vitro potency against the growth of planktonic cells of the tested Haemophilus spp. strains with MIC $<62.5 \mu \mathrm{g} \mathrm{ml}^{-1}$.

As shown in Table 1 , detailed studies with $\mathrm{N}$-ethyl-3amino-5-oxo-4-phenyl-2,5-dihydro- $1 H$-pyrazole-1-carbothioamide revealed that this compound possessed good activity against planktonic cells of the reference strains of $H$. parainfluenzae ATCC 7901 (MIC $=0.49 \mu \mathrm{g} \mathrm{ml}^{-1}$ ), H. parainfluenzae ATCC $51505\left(\mathrm{MIC}=7.81 \mu \mathrm{g} \mathrm{ml}^{-1}\right.$ ), and $H$. influenzae ATCC 10211 (MIC $=0.49 \mu \mathrm{g} \mathrm{ml}^{-1}$ ). This compound was also active against planktonic cells of 20 clinical isolates of $H$. parainfluenzae (MIC $=1.95-31.25$ $\mu \mathrm{g} \mathrm{ml}^{-1}$ ) and of 11 clinical isolates of $H$. influenzae (MIC $=0.24-31.25 \mu \mathrm{g} \mathrm{ml}^{-1}$ ). Moreover, the activity of the tested compound against $H$. parainfluenzae and $H$. influenzae biofilm-forming cells was also determined-it inhibited biofilm formation by reference strains of H. parainfluenzae ATCC 7901 (minimal biofilm inhibitory concentration $[\mathrm{MBIC}]=1.95 \mu \mathrm{g} \mathrm{ml}^{-1}$ ) and $H$. parainfluenzae ATCC $51505\left(\mathrm{MBIC}=15.63 \mu \mathrm{g} \mathrm{ml}^{-1}\right)$ or by 20 clinical isolates of $H$. parainfluenzae $(\mathrm{MBIC}=0.24-31.25$ $\mu \mathrm{g} \mathrm{ml}^{-1}$ ). The tested compound showed the inhibitory effect against biofilm-forming cells of $H$. influenzae ATCC 10211 (MBIC $=15.63 \mu \mathrm{g} \mathrm{ml}^{-1}$ ) or seven $H$. influenzae clinical isolates $\left(\mathrm{MBIC}=0.49-31.25 \mu \mathrm{g} \mathrm{ml}^{-1}\right.$ ). In case of four clinical isolates of $H$. influenzae, MBIC were found to be $>31.25 \mu \mathrm{g} \mathrm{ml}^{-1}$. 
Table 1 The effect of $N$-ethyl-3-amino-5-oxo-4-phenyl-2,5-dihydro$1 H$-pyrazole-1-carbothioamide on the growth of Haemophilus spp. planktonic (MIC) or biofilm-forming (MBIC) cells

\begin{tabular}{|c|c|c|c|c|c|}
\hline \multirow[t]{2}{*}{ Species } & & \multicolumn{2}{|l|}{ Growth } & \multicolumn{2}{|c|}{ Biofilm formation } \\
\hline & & $\begin{array}{l}\text { MIC } \\
\left(\mu \mathrm{g} \mathrm{ml}^{-1}\right)\end{array}$ & $\begin{array}{l}\text { No. of } \\
\text { strains }\end{array}$ & $\begin{array}{l}\text { MBIC } \\
\left(\mu \mathrm{g} \mathrm{ml}^{-1}\right)\end{array}$ & $\begin{array}{l}\text { No. of } \\
\text { strains }\end{array}$ \\
\hline \multirow[t]{9}{*}{$\begin{array}{l}\text { Haemophilus } \\
\text { parainfluenzae }\end{array}$} & $\begin{array}{r}\text { ATCC } \\
7901\end{array}$ & 0.49 & 1 & 1.95 & 1 \\
\hline & $\begin{array}{l}\text { ATCC } \\
51505\end{array}$ & 7.81 & 1 & 15.63 & 1 \\
\hline & \multirow{7}{*}{$\begin{array}{l}\text { Clinical } \\
\text { isolates } \\
(\mathrm{n}=20)\end{array}$} & 0.24 & 0 & 0.24 & 1 \\
\hline & & 0.98 & 0 & 0.98 & 1 \\
\hline & & 1.95 & 1 & 1.95 & 3 \\
\hline & & 3.91 & 1 & 3.91 & 3 \\
\hline & & 7.81 & 3 & 7.81 & 0 \\
\hline & & 15.63 & 7 & 15.63 & 6 \\
\hline & & 31.25 & 8 & 31.25 & 6 \\
\hline \multirow[t]{10}{*}{$\begin{array}{l}\text { Haemophilus } \\
\text { influenzae }\end{array}$} & $\begin{array}{l}\text { ATCC } \\
10211\end{array}$ & 0.49 & 1 & 15.63 & 1 \\
\hline & \multirow{9}{*}{$\begin{array}{l}\text { Clinical } \\
\text { isolates } \\
(\mathrm{n}=11)\end{array}$} & 0.24 & 1 & 0.24 & 0 \\
\hline & & 0.49 & 1 & 0.49 & 1 \\
\hline & & 0.98 & 3 & 0.98 & 1 \\
\hline & & 1.95 & 1 & 1.95 & 2 \\
\hline & & 3.91 & 1 & 3.91 & 1 \\
\hline & & 7.81 & 0 & 7.81 & 1 \\
\hline & & 15.63 & 2 & 15.63 & 0 \\
\hline & & 31.25 & 2 & 31.25 & 1 \\
\hline & & $>31.25$ & 0 & $>31.25$ & 4 \\
\hline
\end{tabular}

To determine the power of the tested compound as an anti-biofilm agent, the MBIC/MIC ratio was assessed. The most frequently $\mathrm{MBIC/MIC}$ ratio ranged from 0.5 to $2 \mu \mathrm{g} \mathrm{ml}^{-1}$, indicating comparable activity of the compound either against planktonic or biofilm-forming cells of $H$. parainfluenzae and $H$. influenzae (Fig. 1). Only in some cases, MBIC/MIC ratio was lower for $H$. parainfluenzae and was higher for $H$. influenzae, indicating strain- and species-dependent activity of the tested compound.

Figure 2 shows the activity of $N$-ethyl-3-amino-5-oxo-4phenyl-2,5-dihydro- $1 H$-pyrazole-1-carbothioamide on the growth or biofilm formation by penicillinase-negative (S85Pen-) and penicillinase-positive (S86Pen+) H. parainfluenzae. In the case of penicillinase-positive isolate, the activity of the compound was significantly higher both on the growth and on the biofilm formation.

The in vitro cytotoxicity of the tested $N$-ethyl-3-amino-5oxo-4-phenyl-2,5-dihydro- $1 \mathrm{H}$-pyrazole-1-carbothioamide compound was presented as percentage viability of vero cells used as an experimental model. According to the results shown in Table 2, after $48 \mathrm{~h}$ of incubation, no cytotoxic effect was observed up to $200 \mu \mathrm{g} \mathrm{ml}^{-1}$ concentration of the

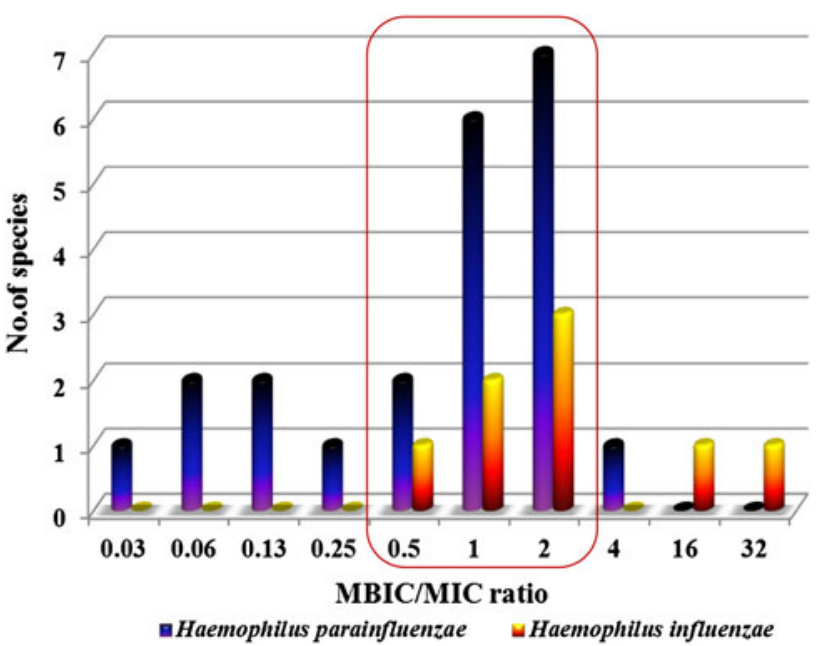

Fig. 1 The effect of $N$-ethyl-3-amino-5-oxo-4-phenyl-2,5-dihydro$1 H$-pyrazole-1-carbothioamide compound on biofilms formation by Haemophilus spp. on the basis of MBIC/MIC ratio

tested compound. The most widely used as a measurement of compound's toxicity is the half maximal effective concentration $\left(\mathrm{EC}_{50}\right)$, as the concentration of the compound where $50 \%$ of its maximal effect is observed; in case of the tested compound $\mathrm{EC}_{50}=278.8 \mu \mathrm{g} \mathrm{ml}^{-1}$. This means that this compound was not toxic to eukaryotic cells at concentrations exerting inhibitory effect against Haemophilus spp., including anti-biofilm activity.

Although the control of bacterial infections has been effective since the discovery of antimicrobial drugs, widespread drug resistance among bacteria has led to a search for new antibacterial agents. However, the finding of biofilm phenotype bacteria, showing usually intrinsic insensitivity to available drugs at standard dosing effective against planktonic cells, has created a necessity to pay more attention to targeted anti-biofilm agents. In this work, we have found that the $\mathrm{N}$-ethyl-3-amino-5-oxo-4-phenyl-2,5-dihydro- $1 \mathrm{H}$-pyrazole-1-carbothioamide possessed good in vitro activity either against free-floating (planktonic) or biofilm-forming cells of Haemophilus spp. Haemophili rods, e.g., pathogenic $H$. influenzae or opportunistic $H$. parainfluenzae are found to be a part of proper microflora of the upper respiratory tract (Kilian, 2007; Murphy et al., 2007). Under favorable conditions, these bacterial species may be the etiologic agents of various and unspecified infections, including those associated with biofilm formation (Trollfors et al., 1985; Black et al., 1988; Mitchell and Hill, 2000; Chin et al., 2005; Musk and Hergenrother, 2006; Rele et al., 2006; Galli et al., 2007; Moxon et al., 2008; Cardines et al., 2009; Drago et al., 2012; Bjarnsholt, 2013). It has been estimated that the biofilms protect microbes from the immune system, antimicrobials, predation or stresses, and are crucial for the development of recurrent and opportunistic diseases (Costerton et al., 1999, 
Fig. 2 The effect of $N$-ethyl-3amino-5-oxo-4-phenyl-2,5dihydro- $1 H$-pyrazole-1carbothioamide compound and ampicillin on the penicillinasenegative (filled diamond S85Pen-) and penicillinasepositive (filled square S86Pen+) Haemophilus parainfluenzae planktonic or biofilm-forming cells (broth without bacteria:

$\left.\mathrm{OD}_{570}=0.09-0.11\right)$
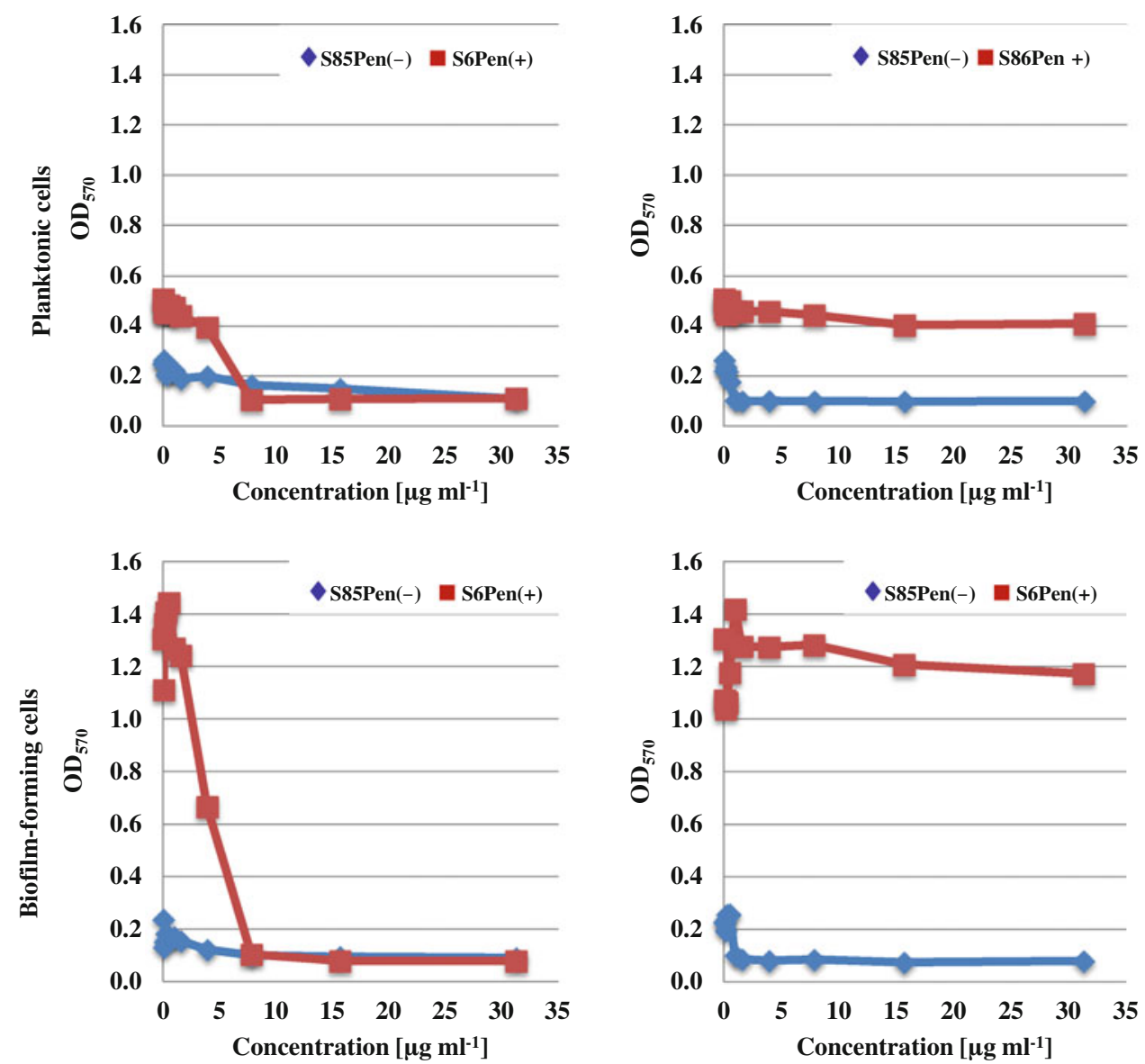

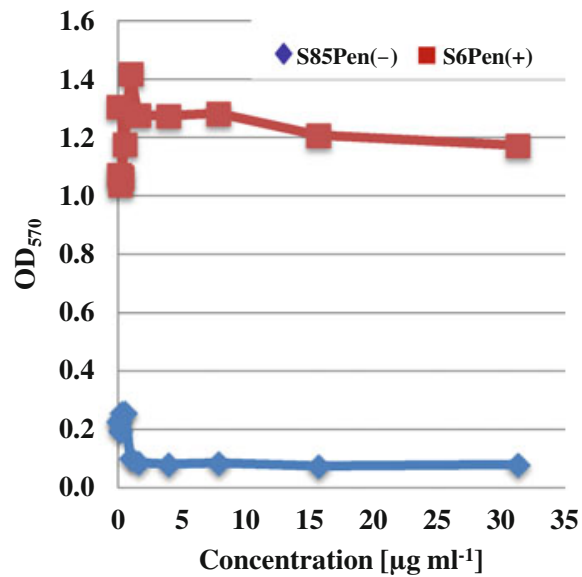

Table 2 The effect of $N$-ethyl-3-amino-5-oxo-4-phenyl-2,5-dihydro$1 H$-pyrazole-1-carbothioamide on vero cells line viability

\begin{tabular}{lc}
\hline Compound concentration $\left(\mu \mathrm{g} \mathrm{ml}^{-1}\right)$ & Cell viability (in \%) $\pm \mathrm{SD}$ \\
\hline 500 & $x$ \\
200 & $37.95 \pm 7.7$ \\
100 & $82.15 \pm 5.7$ \\
50 & $89 \pm 6.6$ \\
25 & $93.55 \pm 4.2$ \\
12.5 & $97.4 \pm 1.7$ \\
6.25 & $98.05 \pm 1.8$ \\
3.15 & $98.75 \pm 2.0$ \\
0 (control) & $100 \pm 0.0$ \\
\hline
\end{tabular}

2003; Donlan, 2002; Prakash et al., 2003; Jain et al., 2007; Wolcott and Ehrlich, 2008).

The pyrazole derivatives are potent and selective inhibitors against DNA gyrase (Reece and Maxwell, 1991; Tanitame et al., 2004; Tse-Dinh, 2007; Farag et al. 2008; Liu et al., 2008; Shiroya et al., 2011). Considering a possible mechanism of anti-biofilm activity of $\mathrm{N}$-ethyl-3-amino-5oxo-4-phenyl-2,5-dihydro- $1 H$-pyrazole-1-carbothioamide, it should be noted that several classes of chemical compounds, e.g., pyrazole or thioamide derivatives, may act as quorumsensing inhibitors (Hentzer and Givskov, 2003; Schillaci et al. 2008; Brackman et al., 2009; Kociolek, 2009; Oancea, 2010). Quorum-sensing phenomenon, which is one of the ways to control biofilms, is a chemical form of bacterial communication via signaling molecules essential for bacterial communities to regulate the group and to synchronize the behavior (Hastings and Greenberg, 1999; Van Houdt et al., 2004; Raffa et al., 2005; Waters and Bassler, 2005; Musk and Hergenrother, 2006; Bjarnsholt and Givskov, 2007; Amer et al., 2008; Labandeira-Rey et al., 2009; Deep et al., 2011). In agreement with the data provided by the literature, pyrazole compounds may act as inhibitors that target this cell-cell signaling mechanism (Tanitame et al., 2004; Musk and Hergenrother, 2006; Tse-Dinh, 2007; Schillaci et al., 2008; Brackman et al., 2009; Oancea, 2010). The number of literature data dealing with regulatory mechanisms controlling the haemophili biofilm formation and a possible effect of different chemical compounds on this process is strongly limited. In our opinion, comparable activity of the tested compound having the ethyl substituent against planktonic or biofilm-forming cells of haemophili rods may be due to the dual activity of pyrazole - main inhibitory effect against DNA gyrase and additional activity 
associated with the disorder of quorum-sensing phenomenon and biofilm formation. We did not find existing studies dealing with effect of the pyrazole compounds on formation or eradication of biofilms created by $H$. influenzae and $H$. parainfluenzae.

It should be mentioned that Lux-S family of quorumsensing regulatory systems involved in production of autoinducer 2 (AI-2), occurring in many bacterial species and functioning as interspecies signaling system, have been identified in $H$. influenzae or $H$. ducrei (Bassler, 1999; Vendeville et al., 2005; Armbruster et al., 2009; Swords, 2012). Ünal et al. (2012) have showed that in nontypeable $H$. influenzae, the two-component signaling system QseB/C was involved in biofilm formation. Daines et al. (2005) and Armbruster et al. (2009) have observed the role of LuxS and AI-2 luxS-dependent factors which control biofilm formation in non-typable $H$. influenzae, but they considered as controversial its importance as virulence factor in pathogenesis of the biofilm-associated infections.

The change in the structure of the substituent has a significant impact on the physicochemical properties of the compound (Hulzebos et al., 2001; Martin et al., 2002). In our study, we synthesized and tested derivatives differing from each other by the type of substituents in the thioamide group. The best results were obtained for the compound having the ethyl substituent. From the microbiological point of view, the key factor is the presence of ethyl group which only slightly increases the mass and the volume of the compound compared to derivatives with cyclohexyl or 4-metoxyphenyl substituents. Additionally, lower molecular weight of ethyl derivative can have a significant effect on the antimicrobial properties of this compound. In our opinion, replacement of ethyl group on cyclohexyl or 4-metoxyphenyl in the tested pyrazole derivatives causes a significant decrease of their activity against Haemophilus spp. Besides, ethyl substituent has a limited conformational freedom which may affect selectivity (Graham, 2001). This is very important information from the point of view of the further modifications of these derivatives and their activity against either biofilm-forming cells or against mature biofilm of Haemophilus spp. In addition, further work is needed to evaluate the role of pyrazole derivatives during biofilm formation and their influence either on adhesive capabilities of haemophili rods or on quorum-sensing phenomenon.

\section{Conclusions}

$\mathrm{N}$-ethyl-3-amino-5-oxo-4-phenyl-2,5-dihydro-1 $\mathrm{H}$-pyrazole-1carbothioamide, $\mathrm{N}$-(4-metoxyphenyl)-3-amino-5-oxo-4-phe- nyl-2,5-dihydro-1 $H$-pyrazole-1-carbothioamide, and $N$-cyclohexyl-3-amino-5-oxo-4-phenyl-2,5-dihydro- $1 H$-pyrazole-1carbothioamide were tested against $H$. influenzae and $H$. parainfluenzae in form of planktonic or biofilm-forming cells. Our study shows that the pyrazoles can be inhibitors acting on planktonic or biofilm-forming cells of Haemophilus spp. Additionally, these results allow to expect that this compound will be the starting substance in the search of antimicrobials with low toxicity, showing inhibitory effect against Gramnegative haemophili rods and including anti-biofilm activity. Further investigations should clarify the mechanism of pyrazoles against biofilm formed by haemophili rods.

\section{Materials and methods}

$N$-substituted-3-amino-5-oxo-4-phenyl-2,5-dihydro$1 H$-pyrazole-1-carbothioamide derivatives

Three $N$-substituted-3-amino-5-oxo-4-phenyl-2,5-dihydro- $1 H$ pyrazole-1-carbothioamide derivatives have been screened for the antibacterial investigations. Obtained compounds were characterized and described earlier (Pitucha et al., 2010).

$\mathrm{N}$-substituted-3-amino-5-oxo-4-phenyl-2,5-dihydro- $1 \mathrm{H}$ pyrazole-1-carbothioamide derivatives were prepared according to Scheme 1. The starting 1-cyanophenylacetic acid hydrazide was prepared in the reaction of corresponding ethyl 1-cyanophenylacetate with $80 \%$ hydrazine hydrate at room temperature. Next, this compound was converted to the 1-(cyanophenylacetyl-4-subtituted)thiosemicarbazide in the reaction of 1-cyanophenylacetic acid hydrazide with ethyl or 4-methoxyphenyl isothiocyanate. Cyclization of these compounds in alkaline or hydrochloric acid medium led to appropriate $N$-substituted-3-amino-5oxo-4-phenyl-2,5-dihydro-1H-pyrazole-1-carbothioamide. $\mathrm{N}$-cyclohexyl-3-amino-5-oxo-4-phenyl-2,5-dihydro- $1 \mathrm{H}$ pyrazole-1-carbothioamide was obtained in the reaction of 1-cyanophenylacetic acid hydrazide with cyclohexyl isothiocyanate. The reaction was carried out in the diethyl ether at room temperature without the separation of linear product.

\section{Bacterial strains}

The haemophili reference species from American Type Culture Collection (ATCC)—H. influenzae ATCC 10211, H. parainfluenzae ATCC 7901, and $H$. parainfluenzae ATCC 51505 were included. Besides, 20 clinical isolates of $H$. parainfluenzae and 11 clinical isolates of $H$. influenzae from the museum of Department of Pharmaceutical Microbiology of Medical University of Lublin were used. 


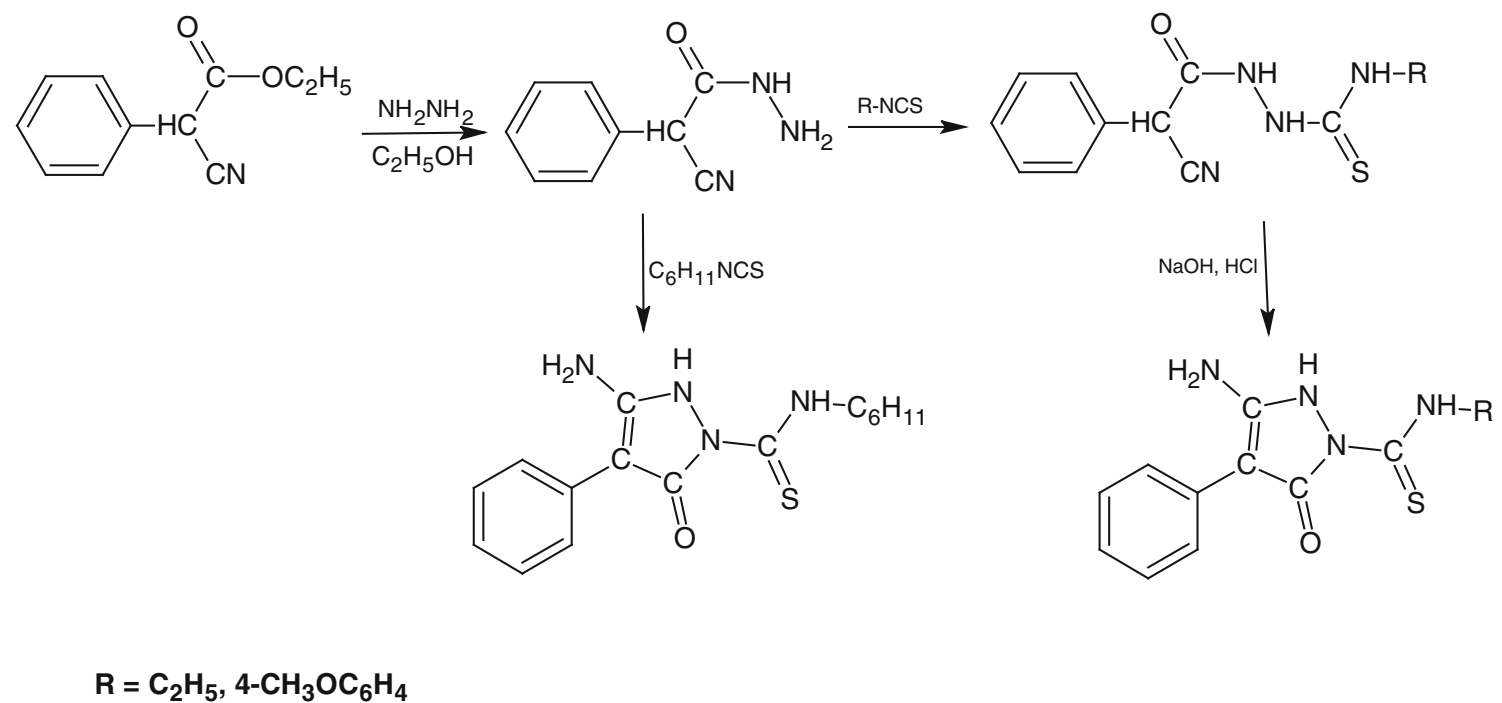

Scheme 1 Synthesis and structure of $N$-substituted-3-amino-5-oxo-4-phenyl-2,5-dihydro- $1 H$-pyrazole-1-carbothioamide

Growth conditions

The Haemophilus chocolate agar (HAEM, bioMerieux) medium with PolyVitex and hemoglobin or tripticasein soy broth (TSB) + Haemophilus test medium supplement (HTMS)_TSB (Biocorp) medium supplemented with HTMS (HTMS SRO158E, Oxoid) with growth factors for haemophili ( $25 \mu \mathrm{g} \mathrm{ml}^{-1}$ of NAD and $15 \mu \mathrm{g} \mathrm{ml}^{-1}$ of hematin) were used. Chocolate agar is blood agar medium that has been heated to open the pyrrole ring, forming haemin (a required growth factor for bacteria lacking hemolysins), providing optimal growth conditions for $H$. influenzae and other fastidious bacteria (Rennie et al., 1992; Han et al., 2006). In clinical microbiology, the TSB medium is used in a variety of procedures, e.g., for the microbiological test procedure of culture media according to the standards (NCLSI, 2000, 2004). However, according to our results, TSB supplemented with HTMS is good as a primary enrichment medium directly inoculated with the various bacteria (Kosikowska and Malm, 2009). The standardized bacterial suspensions with an optical density of 0.5 McFarland standard-150 $\times 10^{6}$ colony-forming units $\mathrm{ml}^{-1}$ in sterile $0.85 \% \mathrm{NaCl}$ were prepared. A stock solutions of $\mathrm{N}$-substituted-3-amino-5-oxo-4-phenyl-2,5-dihydro-1H-pyrazole-1-carbothioamide derivatives at a concentration of $50 \mathrm{mg} \mathrm{ml}^{-1}$ in dimethyl sulfoxide (Sigma) were prepared. The medium with DMSO at a final concentration and without the tested compounds served as control-no microbial growth inhibition was observed.

The bacterial cultures in TSB+HTMS medium with addition of $30 \%$ glycerol were stored at $-70{ }^{\circ} \mathrm{C}$. Before each experiment, bacterial strains were subcultured on HAEM medium and incubated overnight at $35^{\circ} \mathrm{C}$ in about $5 \% \mathrm{CO}_{2}$ atmosphere.
Growth assay

Preliminary in vitro antibacterial activity of compounds $N$ ethyl-3-amino-5-oxo-4-phenyl-2,5-dihydro-1 $H$-pyrazole-1carbothioamide, $\quad \mathrm{N}$-(4-metoxyphenyl)-3-amino-5-oxo-4phenyl-2,5-dihydro- $1 H$-pyrazole-1-carbothioamide, and $N$ cyclohexyl-3-amino-5-oxo-4-phenyl-2,5-dihydro- $1 H$-pyrazole-1-carbothioamide was screened by the broth microdilution method using 96-well polystyrene microplates (NUNC, TC MICROWELL 96F Nunclon D) on the basis of MIC (minimal inhibitory concentration), usually defined as the lowest concentration of the compounds at which there was no visible growth of microorganisms. The antibacterial activity was tested according to EUCAST (2003) procedure with some modifications.

In order to assay the influence of the tested pyrazole derivatives on the growth of haemophili rods, $198 \mu \mathrm{l}$ of TSB + HTMS medium without (control) and with a series of twofold dilution of the tested compounds in the range of final concentration from 1,000 to $62.5 \mu \mathrm{g} \mathrm{ml}^{-1}$ was inoculated with $2 \mu \mathrm{l}$ of the standardized microbial suspension (total volume per each well $-200 \mu \mathrm{l}$ ), and then incubated for $18 \mathrm{~h}$ at $35{ }^{\circ} \mathrm{C}$ in the presence of about $5 \% \mathrm{CO}_{2}$. Then in order to assay the influence of the tested $\mathrm{N}$-ethyl-3-amino-5oxo-4-phenyl-2,5-dihydro- $1 H$-pyrazole-1-carbothioamide with highest inhibitory effect against the planktonic cells of Haemophilus spp., $198 \mu \mathrm{l}$ of TSB+HTMS medium without (control) and with a series of twofold dilution of the tested compound in the range of final concentration from 0.12 to $31.25 \mu \mathrm{g} \mathrm{ml}^{-1}$ was inoculated with $2 \mu \mathrm{l}$ of the standardized microbial suspension (total volume per each well-200 $\mu \mathrm{l}$ ), and then incubated for $18 \mathrm{~h}$ at $35^{\circ} \mathrm{C}$ in the presence of about $5 \% \quad \mathrm{CO}_{2}$. After incubation, spectrophotometric measurements of optical density at wavelength $\lambda=570$ 
$\left(\mathrm{OD}_{570}\right)$ of the bacterial cultures with or without the tested compound were done by using a microplate reader (ELx800 BioTek) in order to determine MIC. The MIC values were determined by comparison to the growth of a control (compound-free) medium. Ampicillin was used as a reference antimicrobial agent on selected $H$. parainfluenzae (penicillinase-positive or penicillinase-negative strains) isolates at the same conditions. The blank control wells without or with twofold dilution of the tested compounds added to TSB+HTMS broth without bacterial suspension were incubated under the same conditions. The experiments were performed in triplicate.

\section{Biofilm assay}

In order to assay the effect of $\mathrm{N}$-ethyl-3-amino-5-oxo-4phenyl-2,5-dihydro-1H-pyrazole-1-carbothioamide on Haemophilus spp. biofilm formation, the method based on staining with $0.1 \%$ crystal violet described previously by Kaplan and Mulks (2005) with some modifications (Kosikowska and Malm, 2009) was used. The activity of the tested compound against biofilm formation was determined on the basis of MBIC, defined as the lowest concentration of the compound at which the biofilm formation was inhibited (Černohorská and Votava, 2008). In order to assay the influence of the tested compound on the biofilm formation by haemophili rods, $198 \mu \mathrm{l}$ of TSB + HTMS medium without (control) and with a series of twofold dilution of the tested compound in the range of final concentration from 0.12 to $31.25 \mu \mathrm{g} \mathrm{ml}^{-1}$ was inoculated with $2 \mu \mathrm{l}$ of the standardized microbial suspension (total volume per each well-200 $\mu \mathrm{l}$ ), and then incubated at $35{ }^{\circ} \mathrm{C}$ in the presence of about $5 \%$ $\mathrm{CO}_{2}$. After overnight incubation of bacterial culture, the medium above the culture was decanted and then the plates were washed extensively several times with distilled water to remove nonadherent or loosely adherent cells, dried in inverted position and stained with $200 \mu \mathrm{l}$ of $0.1 \%$ crystal violet. The plates were left for $15 \mathrm{~min}$ to stain the cells, then washed extensively under distilled water to remove unbound dye. Next, in order to elicit a response to each of the wells, $200 \mu \mathrm{l}$ of isopropyl alcohol (Color Gram 2 R 3-F, bioMerieux) was added and the plates were left at room temperature for $15 \mathrm{~min}$ to solubilize the dye. The optical density of the alcohol-dye solution in each well was read at wave length $\lambda=570\left(\mathrm{OD}_{570}\right)$ by using a microplate reader (BioTek ELx800). Ampicillin was used as a reference compound. The blank control wells without or with twofold dilution of the tested compound added to TSB+HTMS broth without bacterial suspension were incubated under the same conditions. The experiments were performed in triplicate.

\section{Cytotoxicity assay}

The vero cell culture from the American Type Culture Collection (ATCC-84113001) was used in the experiment. The minimum essential medium Eagle (MEM, Sigma) media were supplemented with $10 \%$ fetal bovine serum (Sigma), $100 \mathrm{U} \mathrm{ml}^{-1}$ of penicillin, and $0.1 \mu \mathrm{g} \mathrm{ml}^{-1}$ of streptomycin (Polfa-Tarchomin, Poland). The cell culture was incubated at $37^{\circ} \mathrm{C}$ for $24 \mathrm{~h}$ in the $5 \% \mathrm{CO}_{2}$ atmosphere. A stock solution of $N$-ethyl-3-amino-5-oxo-4phenyl-2,5-dihydro- $1 H$-pyrazole-1-carbothioamide at a concentration of $50 \mathrm{mg} \mathrm{ml}^{-1}$ was dissolved in DMSO (Sigma). The initial concentration of the examined compound in the MEM medium was $500 \mu \mathrm{g} \mathrm{ml}^{-1}$.

$100 \mu \mathrm{l}$ of the vero cell culture prepared was plated into 96-well polystyrene microplates (NUNC) at a cell density $2 \times 10^{4}$ cells per well. After $24 \mathrm{~h}$ incubation at $37^{\circ} \mathrm{C}$, the media were removed and the cells were treated with a solution of the tested compound diluted in the MEM medium including $2 \%$ of serum. The following final concentrations were applied: $3.15,6.25,12.5,25,50,100,200$, and $500 \mu \mathrm{g} \mathrm{ml}^{-1}$. At the same time, the cytotoxicity of solvents was examined. The control cell culture was supplemented with media including $2 \%$ of serum only. The cell cultures were incubated for $48 \mathrm{~h}$ at $37{ }^{\circ} \mathrm{C}$ in the $5 \% \mathrm{CO}_{2}$ atmosphere. Cytotoxicity of the tested compound was estimated using the MTT method, described by Takenouchi and Munekata (1998). The MTT method is a quantitative colorimetric toxicity test, based on the transformation of yellow, soluble tetrazolium salts (3-[4,5dimethylthiazol-2-yl]-2,5-diphenyltetrazolium bromide) to purple-blue insoluble formazane. This process occurs naturally in mitochondria of living cells. After $48 \mathrm{~h}$ incubation with compounds, cell cultures were supplemented with $10 \mu \mathrm{l}$ of $5 \mathrm{mg} \mathrm{ml}^{-1}$ MTT solution per well, and further incubated for $4 \mathrm{~h}$ at $37^{\circ} \mathrm{C}$. Afterwards, $100 \mu \mathrm{l}$ of water solution, including $50 \%$ dimethylformamide and $20 \%$ SDS, per well was added and after the all-night incubation the absorbance was measured by the 96-well plastic plate reader (Organon Teknika) at wavelengths of $\lambda=540$ and $620 \mathrm{~nm}$. The medium with DMSO at tested concentration range without the tested compound served as control-it was not toxic to vero cells line. The experiments were carried out in duplicates.

Open Access This article is distributed under the terms of the Creative Commons Attribution License which permits any use, distribution, and reproduction in any medium, provided the original author(s) and the source are credited.

\section{References}

Agrawal A, Murphy TF (2011) Haemophilus influenzae infections in the $H$. influenzae type b conjugate vaccine era. J Clin Microbiol 49:3728-3732 
Amer FAA, El-Behedy EM, Mohtady HA (2008) New targets for antibacterial agents. Biol Rev Camb Philos Soc 3:46-57

Armbruster CE, Hong W, Pang B, Dew KE, Juneau RA, Byrd MS, Love CF, Kock ND, Swords EW (2009) LuxS promotes biofilm maturation and persistence of nontypeable Haemophilus influenzae in vivo via modulation of lipooligosaccharides on the bacterial surface. Infect Immun 77:4081-4091

Bassler BL (1999) How bacteria talk to each other: regulation of gene expression by quorum sensing. Curr Opin Microbiol 2:582-587

Bekhit AA, Abdel-Aziem T (2004) Design, synthesis and biological evaluation of some pyrazole derivatives as anti-inflammatoryantimicrobial agents. Bioorg Med Chem 12:1935-1945

Bjarnsholt $\mathrm{T}$ (2013) The role of bacterial biofilms in chronic infections. APMIS doi: 10.1111/apm.12099

Bjarnsholt T, Givskov M (2007) Quorum-sensing blockade as a strategy for enhancing host defences against bacterial pathogens. Philos Trans Royal Soc Lond B 362:1213-1222

Black CT, Kupferschmid JP, West KW, Grosfeld JJ (1988) Haemophilus parainfluenzae infection in children with the report of a unique case. Rev Infect Dis 10:342-346

Bottone EJ, Zhang DY (1995) Haemophilus parainfluenzae biliary tract infection: rationale for an ascending route of infection from the gastrointestinal tract. J Clin Microbiol 33:3042-3043

Brackman G, Hillaert U, Van Calenbergh S, Nelis H, Coenye T (2009) Use of quorum sensing inhibitors to interfere with biofilm formation and development in Burkholderia multivorans and Burkholderia cenocepacia. Res Microbiol 160:144-151

Burmølle M, Thomsen TR, Fazli M, Dige I, Christensen L, Homøe P, Tvede M, Nyvad B, Tolker-Nielsen T, Givskov M, Moser C, Kirketerp-Møller K, Johansen HK, Høiby N, Jensen PØ, Sørensen SJ, Bjarnsholt T (2010) Biofilms in chronic infections - a matter of opportunity-monospecies biofilms in multispecies infections. FEMS Immunol Med Microbiol 59:324-336

Cardines R, Giufre M, Atti ML, Accogli M, Mastrantonio P, Cerquetti M (2009) Haemophilus parainfluenzae meningitis in an adult associated with acute otitis media. New Microbiol 2:213-215

Černohorská L, Votava M (2008) Antibiotic synergy against biofilmforming Pseudomonas aeruginosa. Folia Microbiol 53:57-60

Chauhan PMS, Singh S, Chatterjee RK (1993) Antifilarial profile of substituted pyrazoles - a new class of antifilarial agents. Indian J Chem 32B:858-861

Chin CL, Manzel LJ, Lehman EE, Humlicek AL, Shi L, Starner TD, Denning GM, Murphy TF, Sethi S, Look D (2005) Haemophilus influenzae from patients with chronic obstructive pulmonary disease exacerbation induce more inflammation than colonizers. Am J Respir Crit Care Med 172:85-91

Chow AW, Bushkell LL, Yoshikawa TT, Guze LB (1974) Haemophilus parainfluenzae epiglottitis with meningitis and bacteremia in an adult. Am J Med Sci 267:365-368

Coenye T, Nelis HJ (2010) In vitro and in vivo model systems to study microbial biofilm formation. J Microbiol Methods 83:89-105

Comber RN, Gray RJ, Secrist JA (1991) Acyclic analogues of pyrazofurin: syntheses and antiviral evaluation. Carbohydr Res 216:441-452

Cooney TG, Harwood BR, Meisner DJ (1981) Haemophilus parainfluenzae thoracic empyema. Arch Intern Med 141:940-941

Costerton JW, Stewart PS, Greenberg EP (1999) Bacterial biofilms: a common cause of persistent infections. Science 284:1318-1322

Costerton JW, Veeh R, Shirtliff M, Pasmore M, Post C, Ehrlish G (2003) The application of biofilm science to the study and control of chronic bacterial infections. J Clin Invest 112:1466-1477

Daines DA, Bothwell M, Furrer J, Unrath W, Nelson K, Jarisch J, Melrose N, Greiner L, Apicella M, Smith AL (2005) Haemophilus influenzae luxS mutants form a biofilm and have increased virulence. Microb Pathog 39:87-96
Darras-Joly C, Lortholary O, Mainardi JL, Etienne J, Guillevin L, Acar J (1997) Haemophilus endocarditis: report of 42 cases in adults and review. Haemophilus Endocarditis Study Group. Clin Infect Dis 24:1087-1094

Das M, Badley AD, Cockerill FR, Steckelberg JM, Wilson WR (1997) Infective endocarditis caused by HACEK microorganisms. Annu Rev Med 48:25-33

Deep A, Chaudhary U, Gupta V (2011) Quorum sensing and bacterial pathogenicity: from molecules to disease. J Lab Physicians 3:4-11

Donlan RM (2001) Biofilm formation: a clinically relevant microbiological process. Clin Infect Dis 33:1387-1392

Donlan RM (2002) Biofilms: microbial life on surfaces. Emerg Infect Dis 8:881-890

Drago L, De Vecchi E, Torretta S, Mattina R, Marchisio P, Pignataro L (2012) Biofilm formation by bacteria isolated from upper respiratory tract before and after adenotonsillectomy. APMIS 120:410-416

Erwin AL, Smith AL (2007) Nontypeable Haemophilus influenzae: understanding virulence and commensal behavior. Trends Microbiol 15:355-362

European Committee for Antimicrobial Susceptibility Testing (EUCAST) of the European Society of Clinical Microbiology and Infectious Diseases (ESCMID) (2003) Determination of minimum inhibitory concentrations (MICs) of antibacterial agents by broth dilution. EUCAST discussion document E.Dis 5.1

Farag AM, Mayhoub AS, Barakat SE, Bayomi AH (2008) Synthesis of new $N$-phenylpyrazole derivatives with potent antimicrobial activity. Bioorg Med Chem 16:4569-4578

Frankard J, Rodriguez-Villalobos H, Struelens MJ, Jacobs F (2004) Haemophilus parainfluenzae: an underdiagnosed pathogen of biliary tract infections? Eur J Clin Microbiol Infect Dis 23:46-48

Galli J, Calò L, Ardito F, Imperiali M, Bassotti E, Fadda G, Paludetti G (2007) Biofilm formation by Haemophilus influenzae isolated from adeno-tonsil tissue samples, and its role in recurrent adenotonsillitis. Acta Otorhinolaryngol 27:134-138

Gilbert P, Allison DG, McBain AJ (2002) Biofilms in vitro and in vivo: do singular mechanisms imply cross-resistance. J Appl Microbiol (Suppl.) 92:98s-110s

Gökhan-Kelekçi N, Yabanoğlu S, Küpeli E, Salgin U, Ozgen O, Uçar G, Yeşilada E, Kendi E, Yeşilada A, Bilgin AA (2007) A new therapeutic approach in Alzheimer disease: some novel pyrazole derivatives as dual MAO-B inhibitors and antiinflammatory analgesics. Bioorg Med Chem 15:5775-5786

Graham LP (2001) An introduction to medical chemistry, 2nd edn edn. Oxford University Press, Oxford

Hall-Stoodley L, Stoodley P, Kathju S, Høiby N, Moser C, Costerton JW, Moter A, Bjarnsholt T (2012) Towards diagnostic guidelines for biofilm-associated infections. FEMS Immunol Med Microbiol 65:127-145

Han XY, Hong T, Falsen E (2006) Neisseria bacilliformis sp. nov. isolated from human infections. J Clin Microbiol 44:474-479

Hastings JW, Greenberg EP (1999) Quorum sensing: the explanation of a curious phenomenon reveals a common characteristic of bacteria. J Bacteriol 181:2667-2668

Hentzer M, Givskov M (2003) Pharmacological inhibition of quorum sensing for the treatment of chronic bacterial infections. J Clin Invest 112:1300-1307

Hill SL, Mitchell JL, Stockley RA, Wilson R (2000) The role of Haemophilus parainfluenzae in COPD. Chest 117:293S

Hulzebos EM, Janssen PAH, Maslankiewicz L, Meijerink MCM, Muller JJA, Pelgrom SMG, Verdam L, Vermeire TG (2001) The application of structure-activity relationships in human hazard assessment: a first approach, RIVM Report No 601516008, Bilthoven, the Netherlands

Jain A, Gupta Y, Agrawal R, Khare P, Jain SK (2007) Biofilms-a microbial life perspective: a critical review. Crit Rev Ther Drug Carr Syst 24:393-443 
Kaplan JB, Mulks MH (2005) Biofilm formation is prevalent among field isolates of Actinobacillus pleuropneumoniae. Vet Microbiol 108:89-94

Kilian M (2007) Haemophilus. In: Murray PR, Baron EJ, Jorgensen JH, Landry ML, Pfaller MA (eds) Manual of Clinial Microbiology. American Society of Microbiology, Washington DC, pp 636-648

Kociolek MG (2009) Quorum-sensing inhibitors and biofilms. AntiInfect Agents Med Chem 8:315-326

Kosikowska U, Malm A (2009) The preliminary analysis of the ability of biofilm formation in vitro under stationary conditions by Haemophilus parainfluenzae isolates from throat of healthy people. Sepsis 2:203-206

Kumar P, Chandak N, Kaushik P, Sharma C, Kaushik D, Aneja KR, Sharma PK (2012) Synthesis and biological evaluation of some pyrazole derivatives as anti-inflammatory-antibacterial agents. Med Chem Res 21:3396-3405

Labandeira-Rey M, Janowicz DM, Blick RJ, Fortney KR, Zwickl B, Katz BP, Spinola SM, Hansen EJ (2009) Inactivation of the Haemophilus ducreyi luxS gene affects the virulence of this pathogen in human subjects. J Infect Dis 200:409-416

Lasa I, Del Pozo JL, Penades JR, Leiva J (2005) Bacterial biofilms and infection. An Sist Sanit Navar 28:163-175

Lin R, Chiu G, Yu Y, Connolly PJ, Li S, Lu Y, Adams M, FuentesPesquera AR, Emanuel SL, Greenberger LM (2007) Design, synthesis, and evaluation of 3,4-disubstituted pyrazole analogues as anti-tumor CDK inhibitors. Bioorg Med Chem Lett 17:4557-4561

Liu XH, Cui P, Bao-An S, Bhadury PS, Zhu H-L, Wang S-F (2008) Synthesis, structure and antibacterial activity of novel 1-(5substituted-3-substituted-4,5-dihydropyrazol-1-yl)ethanone oxime ester derivatives. Bioorg Med Chem 16:4075-4082

Macedo AJ, Abraham WR (2009) Can infectious biofilm be controlled by blocking bacterial communication? Med Chem 5:517-528

Macfarlane S, Dillon JF (2007) Microbial biofilms in the human gastrointestinal tract. J Appl Microbiol 102:1187-1196

Mahajan N, Havaldar FH, Fernandes PS (1991) Syntheses and biological activity of heterocycles derived from 3-methoxy-1phenyl-1H-pyrazole-5-carboxylate. J Indian Chem Soc 68:245246

Martin YC, Kofron JL, Traphagen LM (2002) Do structurally similar molecules have similar biological activity? J Med Chem 45:4350-4358

Maxwell A (1997) DNA gyrase as a drug target. Trends Microbiol 5:102-108

Mitchell J, Hill S (2000) Immune response to Haemophilus parainfluenzae in patients with chronic obstructive pulmonary disease. Clin Diag Lung Dis 7:25-30

Moxon ER, Sweetman WA, Deadman ME, Ferguson DJ, Hood DW (2008) Haemophilus influenzae biofilms: hypothesis or fact? Trends Microbiol 16:95-100

Murphy TF (2003) Respiratory infections caused by non-typeable Haemophilus influenzae. Curr Opin Infect Dis 16:129-134

Murphy TF, Brauer AL, Sethi S, Kilian M, Cai X, Lesse AJ (2007) Haemophilus haemolyticus: a human respiratory tract commensal to be distinguished from Haemophilus influenzae. J Infect Dis 195:81-89

Musk DJ, Hergenrother PJ (2006) Chemical countermeasures for the control of bacterial biofilms: effective compounds and promising targets. Curr Med Chem 13:2163-2177

National Committee for Clinical Laboratory Standards (2000) Approved standard: M2-A7. Performance standards for antimicrobial disk susceptibility tests, 7th ed. National Committee for Clinical Laboratory Standards, Wayne, Pennsylvania 190871898, USA
National Committee for Clinical Laboratory Standards (2004) Quality control for commercially prepared microbiological culture media; approved standard-third edition. NCCLS document M22-A3. NCCLS, 940 West Valley Road, Suite 1400, Wayne, Pennsylvania 19087-1898 USA

Oancea S (2010) An overview of conventional and alternative strategies for developing new antibacterial agents. Acta Chim Slov 57:630-642

Pillai A, Mitchell JL, Hill SL, Stockley RA (2000) A case of Haemophilus parainfluenzae pneumonia. Thorax 55:623-624

Pitucha M, Mazur L, Kosikowska U, Pachuta-Stec A, Malm A, Popiołek Ł, Rzączyńska Z (2010) Synthesis, structure and antibacterial evaluation of new $N$-substituted-3-amino-5-oxo-4phenyl-2,5-dihydro-1 $H$-pyrazole-1-carbothioamides. Heteroat Chem 21:215-221

Prakash B, Veeregowda BM, Krishnappa G (2003) Biofilms: a survival strategy of bacteria. Curr Sci India 85:1299-1307

Raffa RB, Iannuzzo JR, Levine DR, Saeid KK, Schwartz RC, Sucic NT, Terleckyj OD, Young JM (2005) Bacterial communication (quorum sensing) via ligands and receptors: a novel pharmacologic target for the design of antibiotic drugs. J Pharmacol Exp Ther 312:417-423

Raoult D, Drancourt M, Gallais H, Casanova P (1987) Haemophilus parainfluenzae meningitis in an adult with an inherited deficiency of the seventh component of complement. Arch Intern Med 417:2214

Reece RJ, Maxwell A (1991) DNA gyrase: structure and function. Crit Rev Biochem Mol 26:335-375

Rele M, Giles M, Daley AJ (2006) Invasive Haemophilus parainfluenzae maternal-infant infections: an Australasian perspective and case report. Aust N Z J Obstet Gynaecol 46:258-260

Rennie R, Gordon T, Yaschuk Y, Tomlin P, Kibsey P, Albritton W (1992) Laboratory and clinical evaluations of media for the primary isolation of Haemophilus species. J Clin Microbiol 30:1917-1921

Sanclement JA, Webster P, Thomas J, Ramadan HH (2005) Bacterial biofilms in surgical specimens of patients with chronic rhinosinusitis. Laryngoscope 115:578-582

Schillaci D, Maggio B, Raffa D, Daidone G, Cascioferro S, Cusimano MG, Raimondi MV (2008) 4-Diazopyrazole derivatives as potential new antibiofilm agents. Chemotherapy 54:456-462

Shiroya U, Poshiya A, Patel A, Parikh A, Patel S (2011) DNA-gyrase: a potential and emerging target for finding novel anti-bacterial agents. IJAPR 2:480-492

Steward PS, Costeron JW (2001) Antibiotic resistance of bacteria in biofilm. Lancet 358:135-138

Stoodley HL, Costerton JW, Stoodley P (2004) Bacterial biofilms: from the natural environment to infectious diseases. Nat Rev Microbiol 2:95-108

Sugiura S, Ohno S, Ohtani O, Izumi K, Kitakimado T, Asai H, Kato K (1977) Syntheses and antiinflammatory and hypnotic activity of 5-alkoxy-3-( $N$-substituted carbamoyl)-1-phenylpyrazoles. J Med Chem 20:80-85

Swords WE (2012) Nontypeable Haemophilus influenzae biofilms: role in chronic airway infections. Front Cell Infect Microbiol 2:97. doi:10.3389/fcimb.2012.00097

Takenouchi T, Munekata E (1998) Amyloid beta-peptide-induced inhibition of MTT reduction in PC12h and C1300 neuroblastoma cells: effect of nitroprusside. Peptides 19:365-372

Tanitame A, Oyamada Y, Ofuji K, Fujimoto M, Suzuki K, Ueda T, Terauchi H, Kawasaki M, Nagai K, Wachi M, Yamagishi J (2004) Synthesis and antibacterial activity of novel and potent DNA gyrase inhibitors with azole ring. Bioorg Med Chem 12:5515-5524

Trollfors B, Brorson JE, Claesson B, Sandberg T (1985) Invasive infections caused by Haemophilus species other than Haemophilus influenzae. Infection 13:12-14 
Tse-Dinh YC (2007) Exploring DNA topoisomerases as targets of novel therapeutic agents in the treatment of infectious diseases. Infect Disord Drug Targets 7:3-9

Ünal CM, Singh B, Fleury C, Singh K, de Paz LC, Svensäter G, Riesbeck K (2012) QseC controls biofilm formation of nontypeable Haemophilus influenzae in addition to an AI-2-dependent mechanism. Int J Med Microbiol 302:261-269

Van Houdt R, Aertsen A, Jansen A, Quintana AL, Michiels CW (2004) Biofilm formation and cell-to-cell signalling in Gramnegative bacteria isolated from a food processing environment. J Appl Microbiol 96:177-184

Vendeville A, Winzer K, Heurlier K, Tang CM, Hardie KR (2005) Making 'sense' of metabolism: autoinducer-2, LuxS and pathogenic bacteria. Nat Rev Microbiol 3:383-396
Vlastarakos PV, Nikolopoulos TP, Maragoudakis P, Tzagaroulakis A, Ferekidis E (2007) Biofilms in ear, nose, and throat infections: how important are they? Laryngoscope 117:668-673

Warman ST, Reinitz E, Klein RS (1981) Haemophilus parainfluenzae septic arthritis in an adult. JAMA 246:868-869

Waters CM, Bassler BL (2005) Quorum sensing: cell-to-cell communication in bacteria. Annu Rev Cell Dev Biol 21:319-346

Wolcott RD, Ehrlich GD (2008) Biofilms and chronic infections. JAMA 299:2682-2684 